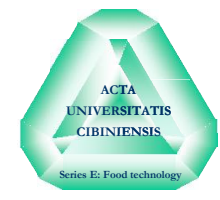

\title{
A STUDY OF FOOD ENTERPRISES' AWARENESS AND BEHAVIORS FOR SOCIAL RESPONSIBILITY
}

\author{
Weimei ZHANG ${ }^{1}$ \\ Central South University of Forestry and Technology, Changsha, China \\ Hunan City University, Yiyang, China
}

\begin{abstract}
This study is undertaken to evaluate and promote the Chinese food enterprises' awareness and behaviors for social responsibility. In the survey, the researcher releases 500 copies of questionnaire to the senior managers in Chinese food enterprises. After excluding invalid respondents, the researcher gets 376 valid copies. Then the researcher conducts a descriptive statistical and factor analysis to the copies of questionnaire. The result shows that: firstly, Chinese food enterprises' awareness of social responsibility is relatively poor; secondly, the majority of food enterprises fulfill their social responsibility passively. Based on the above conclusions, this paper proposes four paths to promote Chinese food enterprises to fulfill social responsibility better, i.e. establish the belief in social responsibility, expand the intensification of food business, make best use of the industrial association and strengthen the government supervision and regulation.
\end{abstract}

Keywords: China; Food Enterprises; Social Responsibility; Awareness; Behaviors; Questionnaire Survey

\section{INTRODUCTION}

The economics defines enterprise as a market-oriented and for-profit economic organization. In this sense, the pursuit of maximized interests of shareholders is taken as the dominant business goal, which is understandable. However, the pursuit of interests should not be the only purpose. The reason for an enterprise's existence or its primary task should be providing material products or services for the community. Enterprises should be the creators of human materials and spirits as well as the fundamental economic units supporting social survival. Therefore, to produce valuable products for people is the meanings of business. As for food enterprises, to provide qualified food for the society should be the minimum requirement and their first prerequisite. If only pursuing for profits at the expense of the health and safety of consumers, this

\footnotetext{
${ }^{1}$ Corresponding author: Weimei Zhang. Mailing address:298, Wuling Road, Yuhua District, Changsha City, Hunan Province, China, 410003. E-mail: zhweimei@126.com .
} 
kind of existence is not an enterprise but a mercenary lethal group, losing its values. In other words, food enterprises should take the most basic social responsibility, pursuing for profits within the limits of ethics and laws, and make commitment to food safety. Only by this way, can food enterprises win a wide recognition of consumers and the society, realizing the long-term development. Therefore, food enterprises should take initiatives to shoulder the social responsibility, which is the inevitable choice for food enterprises adapting to social development, improving competitiveness in global market, and expanding the space for existence and development. In this paper, we use questionnaires to conduct an empirical study of Chinese food enterprises' social responsibility, concerning the current situations and existing problems, in the hope of promoting food enterprises to focus on social responsibility management and practice.

As the economy continues to develop, corporate behavior has become a widespread concern in society. A series of problems have been exposed as certain enterprises deal with consumers, investors, employees, suppliers, local governments, and communities. Some enterprises have bragged about their products, misguided or deceived consumers. Furthermore, they have even provided with unhealthy products for consumers. They have failed to pay their employees in time or been unable to ensure comfortable working conditions. They have tried to avoid compulsory taxes and usually delayed their taxes. They have misused community resources and have destroyed and polluted environment. In this case, some enterprises have begun to explore ways to improve the conditions. Scholars have conducted researches on enterprises' social responsibility. In 1924, Oliver Sheldon, an English scholar, first proposed the concept of Corporate Social Responsibility (CSR). CSR refers to corporate social ethical conduct, which requires enterprises to take the initiative to undertake the environmental, social, and shareholder responsibility when make profits. Merrick (1932) believes that enterprises should serve the society and undertake relevant social responsibility when produce interests for shareholders. Donaldson \& Preston (1995) agrees that enterprises should voluntarily be concerned about the interests of society when carry out business activities. Young (2004) thinks that modern companies should consider the survival and sustainable development, as well as the long-term interests. Taking on social accountabilities could help enterprises win a wide recognition of the society, so that enterprises can achieve the business objectives. Following, more have begun to study the performance of corporate social responsibility, as well as its relationship with corporate financial performance. For instance, Porter \& Kramer (2006) establishes the first corporate social responsibility framework, dividing the corporate social responsibility into four types, i.e. the economic responsibility, the legal responsibility, the ethical responsibility, and the voluntary responsibility. Some scholars, including 
Peters \& al. (2011), Bihari \& Pradhan (2011), André (2012), Lopez \& Fornes (2015), Park \& al. (2015), Patten \& al. (2015) establishes the different corporate social responsibility framework. Many scholars, including Helm (2012), Peters \& Romi (2014), Bice (2015), Ramasastry (2015), Shin (2015), Sundarasen \& al. (2016), etc., believe that there is a positive correlation between corporate social responsibility and corporate financial performance.

\section{MATERIALS AND METHODS}

The methodology of this study is questionnaire. In order to insure the recovery of questionnaires and improve the credibility and accuracy, in this survey we hand out the questionnaires on the spot and recollect them after being filled out anonymously. The survey targets at the trainees who have participated in a training program of corporate SA8000 certification procedures, which was hosted by a food industry association in August 2015. The total trainees are about 600 or so. These trainees work in different food enterprises as senior managers. Most of them are responsible for business management, i.e. they are directly or indirectly engaged in corporate social responsibility management decision. Therefore, their opinions could reflect the management perception and judgement over corporate social responsibility management decision in general. In this survey, we release 500 copies of questionnaire and recollect 447 respondents. After excluding invalid respondents, we get 376 valid copies. The effective recollection rate is $75.2 \%$.

To study food enterprises' awareness and behaviors for social responsibility, we conduct the descriptive statistics of questionnaires. Then, make factor analysis of the original variables. Extract the factors with eigenvalues greater than 1 . We get the new factors as the main factors of original variables.

\section{RESULTS AND DISCUSSIONS}

\section{Food enterprises' attitudes toward social responsibility}

\subsection{Descriptive statistics}

Cognition is the precursor of behavior. The attitudes of employees, especially the senior managers, in food enterprises could exert direct impacts on the fulfillment of social responsibility. Table 1, 2, 3, and 4 generally reflect food enterprises' awareness of social responsibility and their attitudes toward related issues from various perspectives.

The results show that:

Firstly, the results presented in Table 1 show that corporate managers believe that "the purpose for food enterprises undertaking on social responsibility" is 
limited to "obtaining more profits" and "dealing with pressures from public opinions". Corporate social responsibility is not taken as a strategic objective for food enterprises' internal management. The fundamental reason for this situation is that a large majority of food enterprises could not fully understand what corporate social responsibility is or the significance of fulfilling social responsibility to corporate development. They hold the belief that corporate development and social responsibility are mutually contradictory. In their opinion, the conflicts between accountabilities and profits are beyond the coordination between them.

As a matter of fact, some enterprises in developed countries have proved in practice that profits maximization and social responsibility fulfillment are achievable at the same time. Currently, Chinese food enterprises still hold a misconception of social responsibility, which should attract sufficient attention from the field of management science.

Table 1. Your understanding of "the purpose for food enterprises undertaking on social responsibility" is (single or multiple choices)

\begin{tabular}{|l|c|c|}
\hline Option & Number & Proportion (\%) \\
\hline Pressure from public opinion & 344 & 91.5 \\
\hline Obtain government approval & 306 & 81.4 \\
\hline $\begin{array}{l}\text { Establish a brand image and win consumers' } \\
\text { trust }\end{array}$ & 241 & 64.1 \\
\hline Contribute to the society & 97 & 25.8 \\
\hline
\end{tabular}

Secondly, as for the SA8000 certification issue, the results presented in Table 2 show that only $7.1 \%$ of food corporate managers fully understand the SA8000 social responsibility standard system, only $12.2 \%$ basically understand, and $80.6 \%$ are substantially or completely unware of.

Table 2. Do you know SA8000?

\begin{tabular}{|l|l|l|}
\hline Option & Number & Proportion (\%) \\
\hline Have no idea & 39 & 10.4 \\
\hline $\begin{array}{l}\text { Heard of, but do not understand the specific } \\
\text { contents }\end{array}$ & 264 & 70.2 \\
\hline Basically understand & 46 & 12.2 \\
\hline Totally understand & 27 & 7.2 \\
\hline
\end{tabular}

This shows that Chinese food enterprises know little about the SA8000 standard system, not to mention that they carry out the SA8000 certification. In fact, SA8000 is the first international standard for social responsibility. Its purpose is to ensure that all products are in line with social responsibility standard. Compared to food companies in developed countries, Chinese food 
enterprises still have a long way to go, as for the issue of social responsibility management.

The SA8000 will encourage Chinese food enterprises to emphasize on social responsibility and pay more attention to food safety, environmental protection, and labor rights, achieving the sustainable development of enterprises.

Thirdly, as it can be seen from Table 3, in China, the main motivation for food enterprises composing social responsibility report is from the mandatory requirements of government, i.e., relevant government regulations are an important factor $(81.1 \%)$ that drives food enterprises to compose the social responsibility report. The survey also shows that some Chinese food enterprises have begun to associate social responsibility with the market. For example, the market and the corporate internal management are respectively responsible for $40.4 \%$ and $8.2 \%$ of reasons for Chinese food enterprises composing social responsibility reports. This shows that some Chinese food enterprises have begun to concern the significance of fulfilling social responsibility. They have gradually started to take social responsibility management system as an important strategy in order to expand market advantage, improve corporate competitiveness, and obtain more profits.

Table 3. Reasons for enterprises composing social responsibility reports are (single or multiple choices)

\begin{tabular}{|l|l|l|}
\hline Option Number & Proportion (\%) \\
\hline $\begin{array}{l}\text { Pressure from government (administrative } \\
\text { agencies' mandatory requirements) }\end{array}$ & 305 & 81.1 \\
\hline $\begin{array}{l}\text { Pressure from markets (from consumers in product } \\
\text { market and investors in capital market) }\end{array}$ & 152 & 40.4 \\
\hline Corporate pressure (from business management) & 31 & 8.2 \\
\hline Others & 69 & 18.4 \\
\hline
\end{tabular}

Fourthly, in Table 4, respondents' views on eight issues were divided into five grades ( $1=$ totally disagree; $2=$ disagree; $3=$ uncertain; $4=$ =agree; $5=$ totally agree). After recollecting all questionnaires, we use the SPSS19.0 to complete the descriptive statistics.

According to Table 4, for four items, i.e. "food enterprises should take initiatives to undertake social responsibility", "social responsibility management is conductive to food enterprises' sustainable development", "senior managers should promote corporate social responsibility management", "SA8000 certification is significant to food enterprises" are scored lower than 3. It means that respondents hold a lower recognition to the four items. In contrast, the other four items, i.e. "Food enterprises is not necessary to publicize corporate social responsibility report", "social responsibility is a compulsory obligation of state-owned enterprises", "fulfilling social 
responsibility is the burden of enterprises", "social responsibility is the business of local government", are scored higher than 4. It means that respondents are generally negative toward food enterprises' social responsibility.

Table 4. The descriptive statistical analysis of food enterprises' attitudes toward social responsibility

\begin{tabular}{|l|l|l|l|}
\hline Items & Mean & $\begin{array}{l}\text { Standard } \\
\text { deviation }\end{array}$ & sample \\
\hline $\begin{array}{l}\text { Food enterprises should take initiatives to } \\
\text { undertake social responsibility }\end{array}$ & 2.013 & 1.016 & 376 \\
\hline $\begin{array}{l}\text { Social responsibility management is conductive to } \\
\text { food enterprises' sustainable development }\end{array}$ & 2.076 & 1.453 & 376 \\
\hline $\begin{array}{l}\text { Senior managers should promote corporate social } \\
\text { responsibility management }\end{array}$ & 2.147 & 1.260 & 376 \\
\hline $\begin{array}{l}\text { SA8000 certification is significant to food } \\
\text { enterprises }\end{array}$ & 2.163 & 1.351 & 376 \\
\hline $\begin{array}{l}\text { Food enterprises is not necessary to publicize } \\
\text { corporate social responsibility report }\end{array}$ & 4.056 & 1.309 & 376 \\
\hline $\begin{array}{l}\text { Social responsibility is a compulsory obligation } \\
\text { of state-owned enterprises }\end{array}$ & 4.317 & 1.061 & 376 \\
\hline $\begin{array}{l}\text { Fulfilling social responsibility is the burden of } \\
\text { enterprises }\end{array}$ & 4.534 & 1.187 & 376 \\
\hline $\begin{array}{l}\text { Social responsibility is the business of local } \\
\text { government }\end{array}$ & 4.364 & 1.264 & 376 \\
\hline
\end{tabular}

Notice: Respondents' views on eight issues were divided into five grades: 1=totally disagree; $2=$ disagree; $3=$ uncertain; $4=$ agree; $5=$ totally agree.

\subsection{Factor analysis}

To further study the degree of food enterprises' concern for social responsibility we conduct the factor analysis of questionnaires. By analyzing the correlation coefficient matrix of relevant enterprises' attitudes to social responsibility, we find that there is a significant correlation between relevant data. Then, make factor analysis of the eight original variables. Extract the factors with eigenvalues greater than 1 . We get two new factors (we may assume Y1 for the positive attitudes of enterprises to social responsibility, while Y2 for the negative attitudes) as the main factors of eight original variables. The cumulative contribution rate of the two main factors is $70.678 \%$, i.e. the two main factors can reflect $70.678 \%$ of information indicated by the eight original variables. The results of factor analysis are shown in Table 5.

The analysis shows that $\mathrm{Y} 1$ and $\mathrm{Y} 2$ explain the total variance of $70.678 \%$ and Y1 explains the variance of $13.141 \%$, indicating that only a few food 
enterprises are positive to corporate social responsibility in this survey. Y2 explains the variance of $57.537 \%$, indicating that a majority of food enterprises are passive and negative to corporate social responsibility.

Table 5. The factor matrix of attitudes to "corporate social responsibility"

\begin{tabular}{|l|c|c|}
\hline \multicolumn{1}{|c|}{ Items } & $\begin{array}{c}\text { Y1 } \\
\text { (positive } \\
\text { attitude) }\end{array}$ & $\begin{array}{c}\text { Y2 } \\
\text { (negative } \\
\text { attitude) }\end{array}$ \\
\hline $\begin{array}{l}\text { Food enterprises should take initiatives to } \\
\text { undertake social responsibility }\end{array}$ & 0.764 & \\
\hline $\begin{array}{l}\text { Social responsibility management is conductive to } \\
\text { food enterprises' sustainable development }\end{array}$ & 0.872 & \\
\hline $\begin{array}{l}\text { Senior managers should promote corporate social } \\
\text { responsibility management }\end{array}$ & 0.813 & \\
\hline $\begin{array}{l}\text { SA8000 certification is significant to food } \\
\text { enterprises }\end{array}$ & 0.626 & \\
\hline $\begin{array}{l}\text { Food enterprises must publicize corporate social } \\
\text { responsibility report }\end{array}$ & & 0.780 \\
\hline $\begin{array}{l}\text { Social responsibility is a compulsory obligation of } \\
\text { state-owned enterprises }\end{array}$ & & 0.832 \\
\hline $\begin{array}{l}\text { Fulfilling social responsibility is the burden of } \\
\text { enterprises } \\
\text { Social responsibility is the business of local } \\
\text { government }\end{array}$ & & 0.515 \\
\hline $\begin{array}{l}\text { Food enterprises should take initiatives to } \\
\text { undertake social responsibility }\end{array}$ & & 0.872 \\
\hline Eigenvalue & 13.141 & 57.537 \\
\hline Variance contribution rate \% & 57.537 & 70.678 \\
\hline Cumulative variance contribution rate \% & & \\
\hline
\end{tabular}

\section{The implementation of social responsibility in food enterprises}

In the survey, we use five grades to represent the degrees of food enterprises' implementation of social responsibility according to the scores of each item, i.e. 5=full implementation; $4=$ most implementation; $3=$ partial implementation; $2=$ few implementation; $1=$ no implementation. After recollecting all questionnaires, we use SPSS19.0 to make statistical analysis. Results are shown in Table 6.

According to Table 6, for the item "ensure business profits and protect shareholders' interests", the average score is 4.593 , while for the other three items, i.e. "give donations to support public welfare", "save energy, reduce consumption, protect environment, and reduce pollution", and "develop good community relations", the average score of each item is less than 2 . It means 
that Chinese food enterprises lay more stresses on business profits but seldom care about public welfare, environmental protection, community relations, etc.

Table 6. The descriptive statistical analysis of food enterprises' social responsibility behaviors

\begin{tabular}{|c|c|c|c|}
\hline Items & Average & $\begin{array}{l}\text { Standard } \\
\text { deviation }\end{array}$ & $\begin{array}{c}\text { No of } \\
\text { samples }\end{array}$ \\
\hline $\begin{array}{l}\begin{array}{l}\text { Ensure business profits and protect } \\
\text { shareholders' interests }\end{array} \\
\end{array}$ & 4.593 & 1.319 & 376 \\
\hline $\begin{array}{l}\text { Operate with integrity and comply with } \\
\text { industry ethics }\end{array}$ & 2.949 & 1.137 & 376 \\
\hline Pay taxes & 3.397 & 1.225 & 376 \\
\hline Ensure food safety and food quality & 3.279 & 1.221 & 376 \\
\hline $\begin{array}{l}\text { Protect employees' legitimate rights and } \\
\text { safety }\end{array}$ & 3.154 & 1.192 & 376 \\
\hline Give donations to support public welfare & 1.412 & 1.189 & 376 \\
\hline $\begin{array}{l}\text { Save energy, reduce consumption, protect } \\
\text { environment, and reduce pollution }\end{array}$ & 1.051 & 1.021 & 376 \\
\hline Develop good community relations & 1.264 & 1.021 & 376 \\
\hline
\end{tabular}

Notice: reviews on these items above are divided into five grades: 5=full implementation; 4=most implementation; $3=$ partial implementation; $2=$ few implementation; $1=$ no implementation.

According to the survey, there are two reasons for the lagged-behind social responsibility of food enterprises. Firstly, food enterprises develop weak awareness of social responsibility. They lack initiatives to undertake corporate social responsibility. Secondly, for food enterprises' fulfillment of social responsibility, the restriction mechanism is imperfect. Objectively, it lacks effective control. Therefore, food enterprises should establish a correct concept of social responsibility, incorporating social responsibility into senior management decision-making. In addition, improve the restriction mechanism in terms of organizational institutions, laws and regulations. Specifically, we need to take the following measures:

Firstly, to train socially-responsible entrepreneurs. Business leaders play a guiding role in fulfilling social responsibility. Therefore, the first is to train socially-responsible entrepreneurs in order to make sure that food enterprises undertake social responsibility voluntarily. Impose relevant education and guidance on entrepreneurs and strengthen the sense of integrity, professionalism, and law-abiding. Set an example for other entrepreneurs through reporting excellent business leader who cares about food safety and achieves business success, or contributes significantly to the community. By this way, it may promote the healthy growth of entrepreneurs and ensure that they could better undertake and fulfill social responsibility. 
Secondly, to enhance the intensification of food enterprises. Relatively speaking, large enterprises hold a stronger sense of fulfilling social responsibility. From this perspective, we should further improve the intensification of food industry and promote the growth of food enterprises. At present, Chinese food enterprises are still at the stage of lower intensification of production. A large majority of food enterprises are small-sized. Most food enterprises do not possess advanced technologies or facilities, lacking latest technologies for production and new product research and development. Besides, lots of employees are not educated well so that they do not know what social responsibility is. All these problems are not conductive to enterprises' fulfillment of social responsibility. Therefore, we should further promote the intensification of food industry and try to develop large-scale food enterprises.

Thirdly, to establish food industry association and make sure its effectiveness. The food industry association is important for food enterprises to better fulfill their social responsibility. Firstly, the food industry association can provide business and technological support for its member enterprise. By means of offering regular training, it can further improve food enterprises' awareness of food safety and product inspection, ensuring the sustainable and stable production of safety food products. Secondly, the food industry association can urge its member enterprise to organize production following food-related laws and standards. If find illegal activities, such as abuse of food additives, in food enterprises, the food industry association should contact the quality supervision department immediately in case of unqualified food products entering the market and damaging the image of whole industry. Therefore, we should promote the development of food industry association and make it play a role in advocating and promoting the member enterprise to fulfilling social responsibility.

Fourthly, to improve the laws and regulations on food enterprises' social responsibility. According to foreign experiences on food enterprises' social responsibility, in addition to relying on enterprises' self-discipline, an external restriction mechanism may promote enterprises to better fulfill social responsibility. Results of this survey also show that most consumers believe that "legal requirement" and "government guidance" can drive food enterprises to undertake social responsibility. The government should exert its administrative effect properly and introduce corporate social responsibility to food enterprises' management. Through perfecting related laws and regulations, it can guide food enterprises to fulfill their social responsibility. Under the right circumstances, we should establish a reasonable food CSR evaluation system to evaluate food enterprises' fulfillment of social responsibility, realizing the periodical assessment and supervision on food enterprises' behavior. 


\section{CONCLUSIONS}

Based on the results of the survey and relevant analysis, we can draw the following conclusions:

Firstly, Chinese food enterprises' awareness of social responsibility is still relatively weak. In recent years, the issue of food enterprises' social responsibility, especially the food safety issue, has aroused widespread concern. The law enforcement on food safety has been strengthened. Consumers' awareness of food enterprises' social responsibility is gradually growing. All these factors affect Chinese food enterprises' survival and development environment rapidly. Therefore, food enterprises' attitudes to social responsibility, as well as their actions, have become the focus of public attention.

Secondly, for most food enterprises, undertaking social responsibility is a kind of passive behavior. In other words, the degree of fulfilling social responsibility mainly depends on the interaction of food enterprises' internal and external factors, as well as the game equilibrium state between different subjects. It usually relies on the surplus of income to cost in food enterprises. In most food enterprises, the social responsibility issue is still handled in a superficial and passive way in the regulatory framework. Some food enterprises even disseminate greatly their fulfillment of social responsibility, pretending to care about social responsibility. As a matter of fact, it is a localized and short-term mind, rather than global and strategic consideration. These food enterprises usually implement the social responsibility management strategy in a passive way in order to deal with external pressure. Meanwhile, the traditional profit-oriented management has been challenged. The social responsibility could make up the shortcomings of traditional management and become an effective approach of promoting enterprises' sustainable development. In general, social responsibility management will become an essential element of modern food enterprise management instead of a temporary solution.

\section{ACKNOWLEDGEMENTS}

The social science association project in Hunan province (XSPYBZZ007).

\section{REFERENCES}

1. André, R. (2012). Assessing the accountability of the benefit corporation: will this new gray sector organization enhance corporate social responsibility? Journal of Business Ethics, 110(1), 133-150. DOI: 10.1007/s10551-012-1254-1. 
2. Bihari, C. S. \& Pradhan, S. (2011). CSR and performance: the story of banks in India. Journal of Transnational Management, 16(1), 20-35. DOI:10.1080/15475778.2011.549807.

3. Bice, S. (2015). Bridging corporate social responsibility and social impact assessment. Impact Assessment and Project Appraisal, 33(2), 160-166. DOI:10.1080/14615517.2014.983710.

4. Donaldson, T., \& Preston, L. E. (1995). The stakeholder theory of the corporation: concepts, evidence, and implications. Academy of Management Review, 20(20), 65-91. DOI: 10.3138/9781442673496-011.

5. Helm, B. W. (2012). Accountability and some social dimensions of human agency. Philosophical Issues, 22(1), 217-232. DOI: 10.1111/ j.15336077.2012.00226.x.

6. Lopez, B. \& Fornes, G. (2015). Corporate social responsibility in emerging markets: case studies of Spanish MNCs in Latin America. European Business Review. 27(2), 214-230. DOI:10.1108/EBR-03-20130053.

7. Merrick, E. M. (1932). For whom are corporate managers trustees? Harvard Business Review, 45(7), 1147-1148. DOI: 10.2307/1331697.

8. Park, B. I., Ghauri, P. N., Sul, W., \& Choi, S. B. (2015). Symposium: emerging markets, international business, and corporate social responsibility. Emerging Markets Finance \& Trade, 51(2), 291-292. DOI: 10.1080/1540496X. 2015.1021594.

9. Patten, D. M., Ren, Y. \& Zhao, N. (2015). Standalone corporate social responsibility reporting in China: an exploratory analysis of its relation to legitimation. Social and Environmental Accountability Journal. 35 (1), 1731. DOI:10.1080/1540496X.2015.1021594.

10. Peters, G. F., \& Romi, A. M. (2014). Does the voluntary adoption of corporate governance mechanisms improve environmental risk disclosures? evidence from greenhouse gas emission accounting. Journal of Business Ethics, 125(4), 637-666. DOI: 10.1007/s10551-013-1886-9.

11. Porter, M. E., Kramer, M. R. (2006). Strategy and society: the link between competitive advantage and corporate social responsibility. Harvard Business Review, 84(12), 78-92. DOI: 10.1108/sd.2007. 05623 ead.006.

12. Peters, S. Miller, M., \& Kusyk, S. (2011). How relevant is corporate governance and corporate social responsibility in emerging markets? Corporate Governance, 11(4), 429-445. DOI:/10.1108/ 14720701111159262.

13. Ramasastry, A. (2015). Corporate social responsibility versus business and human rights: bridging the gap between responsibility and accountability. Journal of Human Rights. 14(2), 237-259. DOI: 10.1080/14754835.2015.1037953. 
14. Shin, H. D., Lee, N. R., \& Ji, H. P. (2015). Differential effects of strong corporate governance on both professional and voluntary corporate social responsibility activities of the firm. Emerging Markets Finance \& Trade, 51(sup4), S2-S10. DOI: 10.1080/ 1540496X.2014.1013860.

15. Sheldon, O. (1924). The Philosophy of Management. London: Sir Isaac Pit-man and Sons Ltd.

16. Sundarasen, S. D. D., Tan, J. Y., \& Rajangam, N. (2016). Board composition and corporate social responsibility in an emerging market. Corporate Governance, 16(1), 35-53. DOI: 10.1108/CG-05-2015-0059.

17. Young, R. (2004). Dilemmas and advances in corporate social responsibility in Brazil. The work of the Ethos Institute. Natural Resources Forum, 28(4), 291-301. DOI:10.1111/j.1477-8947.2004. 00102.x. 